The $5^{\text {th }}$ International Conference on Family Business and Entrepreneurship

\title{
INTERNAL AND EXTERNAL FACTORS AFFECTING NEW PRODUCT DEVELOPMENT PERFORMANCE
}

\author{
Vanya Cendana ${ }^{*}$, Anton Wachidin Widjaja ${ }^{2}$ \\ ${ }^{1}$ Faculty of Economy and Business, University of Indonesia \\ 2 Faculty of Business, President University \\ Corresponding author: vanyacendana@gmail.com
}

\begin{abstract}
:
The Covid-19 pandemic is strengthening the power of digital disruption. Over the decades, there has been a lot of research focusing on the factors affecting performance of new product development (NPD). However, there are gaps and conflicting results regarding factors affecting new product development performance. This study aims to determine the effect of network externalities and company's strategic orientation mediated by dynamic marketing capability and network capability in Indonesia. Data collection is carried out by simple random sampling, with the population of operational and managerial levels engaged in new product development processes in various firms. 61 Respondents mostly come from Electronic and Fast-Moving Consumer Goods industry, as for the year of work are equally distributed from 2 to above 10 years. The data obtained is processed using the Partial Least Square Structural Equation Modelling (PLS-SEM) method. This method allows us getting measurement and structural model where we test the t-value of each relationship. The result shows a new perspective on Dynamic Marketing Capability and Network Capability. It also shows the need for balancing dimensions of Strategic Orientation. Lastly, Network Externalities is proven to influence the performance of New Product Development.
\end{abstract}

Keywords: NPD Performance, Strategic Orientation, Dynamic Marketing Capability, Network Capability, Network Externalities.

\section{Introduction}

In the pandemic era, there are different challenges for companies in maintaining their business. Adopting from (bisnis.com, 2021), there are 6 challenges faced by companies today, namely adapting to the need of new business which changed digitally, unclear need for-change or future financial priorities, insufficient or ineffective performance management, unclear impact of digital opportunities and IT legacy, lower financial costs but higher effectiveness, NewCo business needs or not integrated acquisition.

In addition to the challenges above, the digital era which has been increasing pressure for more than a decade has significantly exacerbated and accelerated its disruptive power during the pandemic era with the change in sales models towards digital. In digital sales, smaller companies have the opportunity to "match" even the biggest competitors in the market. In addition, rapid changes in customer behavior are also needed. If previously video conferencing providers only focused on corporate market, the pandemic era has made everyone accustomed to video conferencing even for social relations with friends or family, religious events, arts, and various other activities. Then, there are also competitors coming from different industries. Medical device companies usually compete in niche market and by a complex approval process. However, 
the pandemic era made regulations easier to be approved to meet the needs of the crisis. In the end, manufacturers from other industries such as GM and Dyson can achieve success as ventilator manufacturers (Am et al., 2020).

In responding to various challenges in the pandemic era, we can look back to the era of financial crisis in 2009. In this crisis era, companies that invested in innovation resulted in superior growth and post-crisis performance. They can come back stronger, outperform the market by more than 30 percent and continue to deliver rapid growth over the next three to five years (Am et al., 2020). The health concerns brought by COVID-19 inspire innovation in many fields, not only medical and pharmaceutical, but manufacturing and supply chain breakthroughs across all sectors of the economy (Schiller, 2020 \& Montani \& Staglianò, 2021).

Innovation can vary, and one of them is new product development. When placing new product development as one of the strategies for business development, it is better for the company to consider its strategy based on the Ansoff Matrix modified model for innovation. This tool was created by Igor Ansoff, the father of strategic management. Ansoff matrix is simple but very helpful in business development strategy (GURCAYLILAR-YENIDOGAN \& AKSOY, 2018).

In the Ansoff Matrix, new product development is the intersection of new products and existing markets. In a challenging market competition, awareness and acceptance are easier to find for products that are not entirely new, but the product must be new to the company (Fraenkel et al., 2016). In other words, new product for the company but in existing market, namely product development. This strategy has a small risk but large growth potential.

Research by Sajid et al. (2015) found that focus on NPD is more effective and beneficial for organizational financial performance in a competitive environment. In addition, this study also found a positive effect of innovation on company performance. The importance of NPD has grown over the decades and has become one of the dominant drivers of competition in various industries. However, about $33 \%-60 \%$ of all NPDs fail to generate economic returns (Schilling \& Hill, 1998). For decades, NPD has continued to be important in supporting the company's growth. Various studies on things that affect the success of NPD have also been carried out.

Previous research by Fraenkel et al. (2016) shows that successful new product launches (NPLs) occur in dynamic markets (unpredictable, unstable, rapidly changing, and highly competitive) than in static markets, and with innovative sales representatives. In addition, previous research on dynamic capabilities and NPD shows the importance of a company's dynamic capabilities such as the ability to sense and seize product development opportunities (SSC) in the success of its new products (Junfeng \& Wei-ping, 2017). Further on dynamic capabilities, research on Dynamic Marketing Capabilities (DMC) found that DMC increases the likelihood of firm's innovation success and that the firm will be agile in its market operations. DMC plays a much stronger role in NPD for companies operating in mass market than in product customization markets (Mitregga, 2020). However, the research of Jeong et al. (2006) found that contrary to studies where developing and marketing skills were found to be strongly associated with new product success, namely that customer orientation did not have a significant positive effect on all measures of NPD performance. Then, other studies also examine the strength of network capability as one of the factors that limit the effective use of the company's internal resources to develop dynamic capabilities (Junfeng \& Wei-ping, 2017). This indirectly implies that dynamic capabilities as one of NPD success factors will be disrupted by the strength of network. However, there is also conflicting study which confirms that network capabilities contribute to the exchange and combination of resources within network for product innovation that can change insights from market orientation or entrepreneurship to better performance outcomes ( $\mathrm{Mu}$ et al., 2017).

There are so many contradictions about factors influencing NPD performance even though NPD is an important strategy which drives company growth. Therefore, this study aims to examine the internal and external factors affecting NPD performance and add to the existing body of literature. Furthermore, this study will also examine Dynamic Marketing Capability (DMC) and network capability, which has not been much explored in previous research on the relationship with NPD Performance. 


\section{Literature Review}

New Product Development (NPD)

New product development project determines the whole process in forming new products, which is one of strategic management applications. Strategic management concept itself is part of project management research literature which receives great attention. This project usually uses 4 strategies to achieve goals of project team and business strategy at operational level, namely product advantage, product time to market, customer intimacy, and cost advantage (Iamratanakul, 2014). Product development performance is critical, especially for those in technology-driven industries such as smartphones, which is growing very fast. Better understanding of factors related to product success can help companies focus and make better use of valuable processes and materials, such as resources dedicated to $\mathrm{R} \& \mathrm{D}$, product processes, and market share of new products (Zirger \& Maidique, 1990).

According to Cooper and Kleinschmidt (2007) in Cassia \& Massis (2012), nine critical success factors for NPD are high quality processes, business unit strategies, adequate human resources and money. R\&D spending, high-quality project teams, commitment and active role of senior management, innovative climate and culture, use of cross-functional project teams, senior management accountability for new product results. Where processes, strategies, resources, and R\&D expenditures are more important factors on performance.

To recoup development costs and bring economic returns characterized by rapid product obsolescence and market fragmentation, a company's new product development must fulfil two important objectives, which are minimizing time to market and maximizing the fit between customer needs and product specification (Schilling \& Hill, 1998). This means that resources, expenditures, economic returns, and many other things can help in assessing NPD. Tolonen et al. (2017) also mentions the new product development process (NPD) as a strategic activity with metrics such as short time-to-market, total cost, and product performance. These three aspects are equally important to the long-term success of the company. In this journal, we will use the definition by Falasca et al. (2017) \& Mu et al. (2017) of NPD Performance, market reception and profits following the introduction of new product or service to market which outcomes are increased profit, relative success compared to competitors' products, good fit with customer needs, and increased market share.

\section{Strategic Orientation and NPD Performance}

Strategic orientation gives direction to companies to face competition and meet customer needs, as well as set of activities and behaviors aiming to achieve innovation goals (Ende et al., 2020 \& Jeong et al., 2006). It is the core of corporate strategy, which is complex and has many concepts and perspectives (Wang \& Dang, 2013). According to Adis (2009), strategic orientation originally comes in the form of market orientation, which then extended to strategic orientation focusing on customer orientation. However, there exist different theories which suggest that market and entrepreneurial orientation are the most important dimensions, with the market orientation itself embodies the classic marketing principle stating that firms need to stay close to their customers. Furthermore, entrepreneurial orientation reflects an organization's response to future and potential market needs which behavior is innovative, proactive toward opportunities, and tolerant of risk (Mu et al., 2017). Jeong et al. (2006) highlights customer orientation and technology orientation as dimensions of strategic orientation, which positively influenced new product development performance in highly uncertain market. However, customer orientation doesn't have significant effect on NPD performance. In contrast, Feng et al. (2012) highlight the customer orientation as an important factor for shortening time-to-market of new products.

In line with Feng et al. (2012) and Jeong et al. (2006), Adis (2009) also categorized customer orientation and technology orientation as dimensions of strategic orientation, with addition of competitor orientation and inter-functional coordination.

Another different perspective comes from Wang \& Dang (2013), proposing that learning and innovation orientation are dimensions of strategic orientation. However, this journal will adopt market and entrepreneurial orientation from $\mathrm{Mu}$ et al. (2017) as dimensions of strategic orientation since it is stated 
that the two of them are the most important ones. In addition, the most recent research comes from Mu et al. (2017). Furthermore, most previous researches used customer and technology orientation as dimensions, hence, this journal is expected to add different perspective to strategic orientation, align with $\mathrm{Mu}$ et al. (2017). Mu et al. (2017) finds positive effects between market orientation, entrepreneurial orientation and NPD performance. Therefore, it is hypothesized that:

H1: Strategic orientation positively affects NPD Performance

\section{Mediating role of Dynamic Marketing Capability}

Teece et al. (1997) refer to a new capability to achieve competitive advantage as 'dynamic capability' which emphasizes two aspects that were not the main focus in the previous strategic perspective. Dynamic Capability is defined as the company's ability to integrate, build, and reconfigure internal and external competencies to cope with a rapidly changing environment. Furthermore, the term 'dynamic' means the capacity to adapt to a changing business environment by renewing competencies. Certain innovations are needed when time-to-market, rapid technological change, and the nature of competition and future markets are difficult to determine. Meanwhile, the term 'capabilities' emphasizes the key role of strategic management in adapting, integrating, and reconfiguring internal and external organizational skills, resources, and functional competencies appropriately to suit the changing environment.

Previous studies on the effect of dynamic capability on NPD have shown that a company's dynamic capabilities such as the ability to sense and seize product development opportunities are important in the success of its new product. According to Teece (2007), sensing consists of "analytical systems for learning and sensing, filtering, shaping, and calibrating opportunities". Thus, sensing includes all the processes that help organizations collect and analyze market information to learn about customers, competitors, and channel members. Meanwhile, approval is concerned with sensing opportunities through new products, processes, or services, thereby increasing research and development activities.

The idea behind differentiating DMCs from other dynamic capabilities is based on the diversity of dynamic capabilities in the literature and the relative importance of marketing as a key business function (Mitrega, 2020). DMC emerged from dynamic capability (Teece, 2007), which is the responsiveness and efficiency of cross-functional business processes, including product development management, supply chain management, and customer relationship management, to create and deliver customer value in response to market changes ( Srivastava, Shervani, \& Fahey, 1999 in Xu et al., 2018). DMC is a cross-functional process, and in terms of market knowledge, DMC is just the basis of DMC, not the core. As with DCV, resource reconfiguration routines form the cornerstone of DMC. Specifically, DMC is defined as the process by which a firm reconfigures its marketing resources for market anticipation (Mitręga, 2020).

DMC increases the likelihood of a company's innovation success and is more agile in its market operations. In particular, DMC plays a much stronger role in NPD which firms operating in mass-market than firms operating in product customization. DMC as a strategic orientation is more effective for companies that introduce product/service innovations to various market segments and various customers in general, rather than close customer relationships. Furthermore, DMC can be used as a useful management tool for various companies in managing innovation, and is effective for innovation success and agility, even when combined with other factors such as customer orientation, marketing budget or CRM (Mitręga, 2020). In this journal, we use the definition of DMC by Mitrega et al. (2020) \& Falasca et al. (2017), market-dependent processes oriented at reconfiguration of firm's marketing resources. Furthermore, previously mentioned variable, strategic orientation, is an important driver of a key element of dynamic capabilities, called adaptive capability (Zhou \& Li, 2010). Therefore, it is hypothesized that:

H2a: Strategic Orientation positively influences Dynamic Marketing Capability

H2b: Dynamic Marketing Capability (DMC) mediates the relationship between strategic orientation and NPD performance

Mediating role of Network Capability 
Social capital is defined as a set of resources obtained by the company through social relationships, with the aim of achieving goals. Just as individuals can leverage social capital from their social networks to facilitate some action or goal attainment, so organizations can extract resources from their networks. However, a social network only conveys social capital if its social ties are beneficial to the attainment of goals. (Gabbay \& Leenders, 1999).

A previous study by Junfeng \& Wei-ping (2017) observed a negative moderating effect of network strength in the relationship between internal resources and dynamic capability, and a positive relationship between dynamic capability and new product success. In fact, technology capital and human resources have complementary effects on dynamic capability when the company's network strength is weak but become substitutes when the network strength is strong.

Contrary to the study by Junfeng \& Wei-ping (2017), network capabilities contribute to the exchange and combination of network resources for product innovation. With network capabilities, companies can change insights from market orientation or entrepreneurship to better performance outcomes. The implementation of market orientation or entrepreneurial orientation also requires managers who are responsible for NPD to have adequate networking capabilities in order to successfully implement policies related to market orientation or entrepreneurial orientation (Mu et al., 2017).

Wang \& Dang (2013) finds that more strategic orientation will be associated with more network capability. This means that network orientation is linked with strategic orientation, in which network capability has a mediate role in the relationship between strategy oriented and innovation performance. In addition, this journal chooses aligned definition with Fang \& Dang (2013) about definition of network capability, which is Enterprise developed and utilized inter-organization network relationship, from the external network main body's ability to get all kinds of resources, and which ability to get all kinds of resources from the external network. Therefore, it is hypothesized that:

H3a: Strategic Orientation positively influences Network Capability

H3b: Network Capability mediates the relationship between strategic orientation and NPD Performance

\section{Network Externalities and NPD Performance}

Network externalities, also called network effects, denotes a phenomenon where the value of the product does not depend on the product itself but on other complementary products or users with whom the customer can interact (Sahay and Riley, 2003 in Molina-Castillo et al., 2011). Previous researches find that network externalities change customer needs and behavior, such as the need to wait for review and word of mouth from others before adopting the product, and thus has important implications for marketing strategy (Srinivasan et al., 2004). Furthermore, Molina-Castillo et al. (2011) argue that network externalities are divided into direct (number of users) and indirect (complementary products), which is often referred to by previous researches as hardware (primary product) and software (complementary product).

As presented by Molina-Castillo et al. (2011), both direct and indirect network externalities play an important role on NPD performance. To be specific, Molina-Castillo et al. (2011) mentioned that direct network externalities have a stronger role in long-term performance, while indirect network externalities are stronger in driving short-term performance. Nevertheless, an increasing number of main product users increases the availability of complementary products, which in turn increases the utility of the main product (Stremersch et al., 2007). This implies a direct influence of indirect network externalities toward the direct network externalities. Therefore, it is hypothesized that:

H4: Indirect Network Externalities positively influence Direct Network Externalities

H5a: Direct Network Externalities positively affect NPD Performance

H5b: Indirect Network Externalities positively affect NPD Performance

Therefore, research model is as shown in Figure 1 below. 


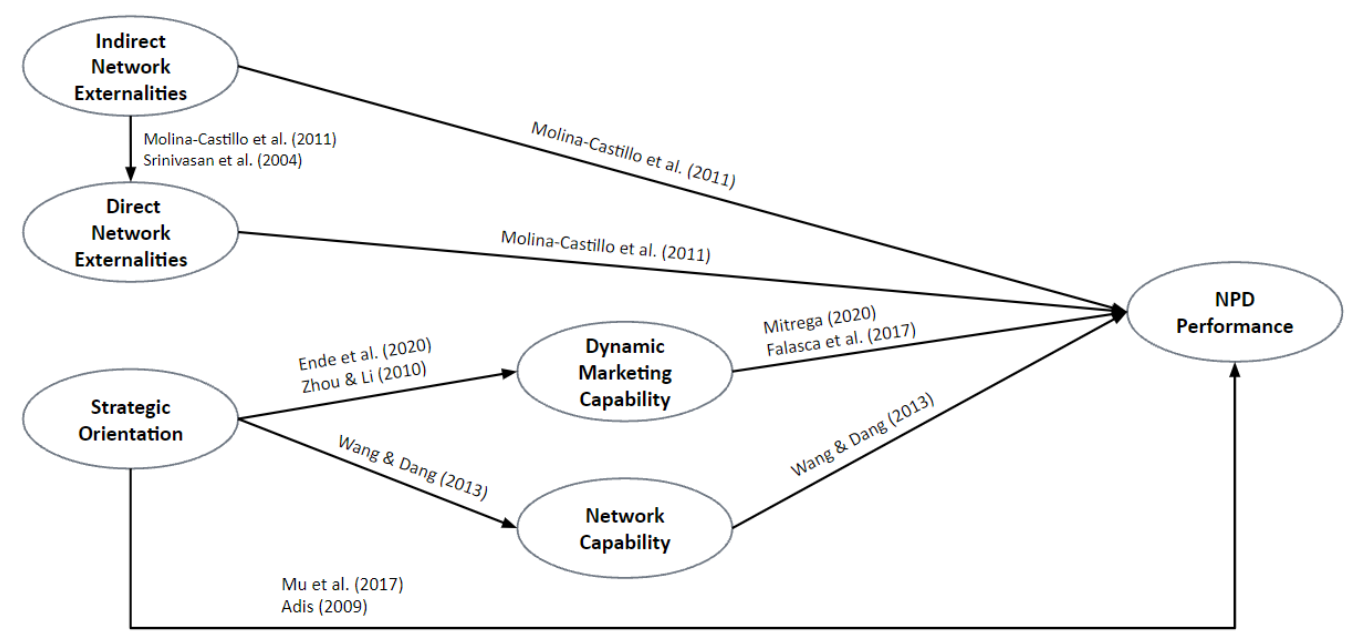

Figure 1. Research Model

(Source: Various researches)

\section{Research Method}

\section{Data Collection}

The sample for this research is collected from September to October 2021 by using simple random sampling method without replacement, which means that a unit can only be sample for one time and then eliminated (Stopher, 2016) with the criteria of employees whose work related to NPD process (such as Marketing, $\mathrm{R} \& \mathrm{D}$, Supply Chain) from any levels in organization. It is due to the development of NPD which is at the operational level, which means that both operational and managerial level are familiar with the whole process. Furthermore, this research would like to see perspectives from both operational and managerial level. The data will be collected by using online questionnaire with Likert scale 1 to 7 . It is due to the use of questionnaires as a data collection tool in which several conditions are met, including the need for quantitative data processing, also clearly defined and identified target audiences who understand what is asked in the questionnaire (Marshall, 2005). Moreover, Marshall (2005) stated that it is better to use a validated questionnaire since it allows comparison with other studies, time and resource saving, and easier on getting results published. Thus, this research used various validated questionnaires from previous researches which is listed in 3.2 and appendix. Respondents are from departments related to New Product Development Process which also familiar to the Performance, which comes from several conditions below:

Table 1. Respondents Background

\begin{tabular}{ccc}
\hline Industry & \#Respondents & \%Respondents \\
\hline Electronics & 18 & $29.5 \%$ \\
FMCG & 16 & $26.2 \%$ \\
Others & 37 & $44.3 \%$ \\
Total & 61 & $100 \%$ \\
Years of Related Work & \#Respondents & $\%$ Respondents \\
0 to 2 years & 7 & $11.5 \%$ \\
2 to 5 years & 20 & $32.75 \%$ \\
5 to 10 years & 14 & $23 \%$ \\
Above 10 years & 20 & $32.75 \%$ \\
Total & 61 & $100 \%$ \\
\hline
\end{tabular}

Source: Questionnaire results 
Operationalization of Variables

Validated questionnaires are obtained from several previous researches, which is listed in the table below. See Appendix for the complete list of indicators.

Table 2. Sources of Questionnaire

\begin{tabular}{cc}
\hline Construct Variable & Source \\
\hline NPD Performance & Mu et al. (2017) \\
Strategic Orientation & Mu et al. (2017) \\
Dynamic Marketing Capability & Falasca et al. (2017) \\
Network Capability & Mu et al. (2017) \\
Direct Network Externalities & Molina-Castillo et al. (2011) \\
Indirect Network Externalities & Molina-Castillo et al. (2011) \\
\hline Source: Mu et al. (2017), Falasca et al. (2017), Molina-Castillo et al. (2011)
\end{tabular}

\section{Descriptive Statistics}

The data is then being processed by using descriptive statistics first.

Table 3. Descriptive Statistics

\begin{tabular}{cc}
\hline Construct Variable & Variable Score \\
\hline NPD Performance & 5.39 \\
Strategic Orientation & 5.06 \\
Dynamic Marketing Capability & 5.28 \\
Network Capability & 5.34 \\
Direct Network Externalities & 5.54 \\
Indirect Network Internalities & 5.48 \\
\hline
\end{tabular}

The results show the distribution of the respondents' responses to each of the variables contained in this study, which are in the high/good category with the average obtained are in the range of 4.60-5.79 and the standard deviation is in the range of 1.03 to 2.08 .

\section{Measure Validity and Reliability}

To test the validity and reliability of the data, convergent validity and reliability test using average variance extracted (AVE) is used. From the convergent validity, we excluded several indicators which are not valid. Then, we continue to the next test, which is reliability test using Cronbach's alpha, composite reliability, and average variance extracted. The standard for AVE is above 0.5 which indicates that the indicators can better reflect the characteristics of each research variable in the model (Srinivasan et al., 2002 in Gu et al., 2019 ) and therefore, all indicators are valid and reliable as shown on table 4 below.

Table 4. Construct Validity and Reliability

\begin{tabular}{|c|c|c|c|c|c|}
\hline $\begin{array}{l}\text { Construct } \\
\text { Variable }\end{array}$ & Item & Loading Factor & Cronbach's Alpha & $\begin{array}{l}\text { Composite } \\
\text { Reliability }\end{array}$ & AVE \\
\hline \multicolumn{3}{|c|}{ NPD Performance } & 0.972 & 0.975 & 0.764 \\
\hline \multicolumn{3}{|c|}{ Relative Sales, Share, ROI } & 0.967 & 0.972 & 0.793 \\
\hline & NP1 & 0.857 & & & \\
\hline & NP2 & 0.889 & & & \\
\hline & NP3 & 0.905 & & & \\
\hline & NP4 & 0.916 & & & \\
\hline & NP5 & 0.861 & & & \\
\hline & NP6 & 0.899 & & & \\
\hline & NP7 & 0.914 & & & \\
\hline & NP8 & 0.876 & & & \\
\hline
\end{tabular}




\begin{tabular}{|c|c|c|c|c|}
\hline NP9 & 0.897 & \multirow{5}{*}{0.881} & & \\
\hline \multicolumn{2}{|c|}{ Meeting Objectives } & & \multirow[t]{4}{*}{0.927} & \multirow[t]{4}{*}{0.809} \\
\hline NP10 & 0.881 & & & \\
\hline NP11 & 0.882 & & & \\
\hline NP12 & 0.934 & & & \\
\hline \multicolumn{2}{|c|}{ Strategic Orientation } & 0.92 & 0.935 & 0.642 \\
\hline \multicolumn{2}{|c|}{ Market Orientation } & 0.938 & 0.946 & 0.595 \\
\hline MO2 & 0.713 & & & \\
\hline MO3 & 0.827 & & & \\
\hline MO4 & 0.734 & & & \\
\hline MO5 & 0.812 & & & \\
\hline MO6 & 0.728 & & & \\
\hline MO7 & 0.762 & & & \\
\hline MO8 & 0.739 & & & \\
\hline MO9 & 0.822 & & & \\
\hline MO10 & 0.753 & & & \\
\hline MO11 & 0.752 & & & \\
\hline MO13 & 0.86 & & & \\
\hline MO14 & 0.736 & & & \\
\hline \multicolumn{2}{|c|}{ Entrepreneurial Orientation } & 0.882 & 0.91 & 0.628 \\
\hline $\mathrm{EO} 2$ & 0.783 & & & \\
\hline EO6 & 0.774 & & & \\
\hline EO7 & 0.763 & & & \\
\hline EO8 & 0.861 & & & \\
\hline EO9 & 0.778 & & & \\
\hline EO10 & 0.791 & & & \\
\hline \multicolumn{2}{|c|}{ Dynamic Marketing Capability } & 0.936 & 0.946 & 0.662 \\
\hline $\mathrm{DMC} 1$ & 0.772 & & & \\
\hline DMC2 & 0.802 & & & \\
\hline DMC3 & 0.745 & & & \\
\hline DMC4 & 0.848 & & & \\
\hline DMC5 & 0.852 & & & \\
\hline DMC6 & 0.813 & & & \\
\hline DMC7 & 0.819 & & & \\
\hline DMC8 & 0.813 & & & \\
\hline DMC9 & 0.853 & & & \\
\hline \multicolumn{2}{|c|}{ Network Capability } & 0.924 & 0.936 & 0.678 \\
\hline $\mathrm{NC} 3$ & 0.823 & & & \\
\hline $\mathrm{NC} 4$ & 0.714 & & & \\
\hline NC6 & 0.809 & & & \\
\hline $\mathrm{NC7}$ & 0.94 & & & \\
\hline NC8 & 0.788 & & & \\
\hline $\mathrm{NC} 10$ & 0.732 & & & \\
\hline $\mathrm{NC} 11$ & 0.931 & & & \\
\hline \multicolumn{2}{|c|}{ Indirect Network Internalities } & 0.773 & 0.897 & 0.813 \\
\hline INE1 & 0.925 & & & \\
\hline INE2 & 0.877 & & & \\
\hline \multicolumn{2}{|c|}{ Direct Network Externalities } & 0.865 & 0.917 & 0.786 \\
\hline DNE1 & 0.912 & & & \\
\hline DNE2 & 0.876 & & & \\
\hline DNE3 & 0.872 & & & \\
\hline
\end{tabular}

Hence, the data is ready to be statistically tested for hypothesis testing. 


\section{Results and Discussion}

\section{Results}

The data then is analyzed using Partial least squares structural equation modelling (PLS-SEM) since the sample size is small and the model is complex. It is stated that PLS-SEM helps in achieving higher statistical power and demonstrating better convergence behavior than CB-SEM for the conditions of smaller sample size and complex model (Henseler, 2010; Reinartz et al., 2009 in Hair et al., 2014). Goodness of Fit Index also resulted in good and close fit for the model.

Table 5. Direct Influence Testing Summary

\begin{tabular}{lccc}
\hline \multicolumn{1}{c}{ Direct Influence } & t-value & $\mathrm{P}$ & Decision \\
\hline $\begin{array}{l}\text { Relative sales, market share, and return on investment as } \\
\text { dimension of NPD Performance }\end{array}$ & 551.746 & $0.000^{* *}$ & Accepted \\
Meeting objectives as dimension of NPD Performance & 55.790 & $0.000^{* *}$ & Accepted \\
H1: Strategic Orientation $\rightarrow$ NPD Performance & 1.254 & 0.210 & Rejected \\
$\begin{array}{l}\text { Market Orientation as Dimension of Strategic Orientation } \\
\text { Entrepreneurial Orientation as Dimension of Strategic }\end{array}$ & 109.554 & $0.000^{* *}$ & Accepted \\
$\begin{array}{l}\text { Orientation } \\
\text { H2a: Strategic Orientation } \rightarrow \text { Dynamic Marketing Capability }\end{array}$ & 27.279 & $0.000^{* *}$ & Accepted \\
H2b: Mediating role of Dynamic Marketing Capability & 0.910 & 0.363 & Accepted \\
H3a: Strategic Orientation $\rightarrow$ Network Capability & 1.289 & 0.198 & Rejected \\
H3b: Mediating role of Network Capability & 0.481 & 0.630 & Rejected \\
H4: Indirect Network Externalities $\rightarrow$ Direct Network & 4.187 & $0.000^{* *}$ & Accepted \\
Externalities & & & \\
H5a: Direct Network Externalities $\rightarrow$ NPD Performance & 3.281 & $0.001^{* *}$ & Accepted \\
H5b: Indirect Network Externalities $\rightarrow$ NPD Performance & 4.055 & $0.000^{* *}$ & Accepted \\
\hline
\end{tabular}

$* * \mathrm{P}<0.05$

From 8 hypotheses, there are 4 hypotheses accepted while the other 4 are rejected. Therefore, as we can see from the table, the dimensions of NPD Performance both represent the variable NPD Performance. Market and Entrepreneurial Orientations are also accepted as the dimensions of Strategic Orientation. Strategic Orientation also has a positive significant influence on Dynamic Marketing Capability, but not Network Capability. Last, Indirect Network Externalities influence Direct Network Externalities, and both of them have positive significant effects on NPD Performance.

\section{Discussion}

Inline, with Molina-Castillo et al. (2011) and Stremersch et al. (2007), this research also found the positive influences of indirect and direct network externalities toward NPD Performance. We also found the influence of indirect network externalities to the direct network externalities as expected. Moreover, our results showed that strategic orientation, which influenced dynamic capability, also influenced dynamic marketing capability. However, contrary to previous researches related to the positive effect of dynamic marketing capability to NPD Performance, the results show otherwise. Dynamic marketing capability doesn't have much previous researches and therefore, this research is giving another view on the body literature of DMC and its relationship with NPD Performance.

Another conflicting result is the relationship between strategic orientation, network capability, and NPD Performance. Similar to DMC, there are only a few numbers of literature related to network capability and NPD performance. In contrast with $\mathrm{Mu}$ et al. (2017), this research could not find any effect of network capability toward NPD performance. We also could not find the relationship between strategic orientation with network capability as what is found in Mu et al. (2017). This also adds a new perspective to the body literature of Network Capability and its effect on NPD performance. 
Lastly, our results suggested that there is no significant effect of strategic orientation to NPD Performance. Contrary to our expectation, this result is align with previous researches related to market and entrepreneurial orientation as the dimensions of strategic orientation, in which the joint effect between them is found to be conflicting idea-generating processes, which led to information overload and waste of time in sorting the overloaded information (Morgan et al., 2014). Furthermore, firms manifesting high EO should have low MO to perform better compared to simultaneously co-develop both dimensions. This might be because market orientation cannot capture rare circumstances which firms need or is irrelevant to consumer demands. Lastly, high levels of market orientation may also create inertia, not fostering creative thinking (Beliaeva et al., 2018).

\section{Conclusion and Implications}

Internal and external factors related to NPD Performance are being found out through this research. The results suggest that network externalities, both direct and indirect, significantly and positively affect NPD performance. We also found several new things in this research, including the positive relationship of Strategic Orientation and Dynamic Marketing Capability, which is new in the body literature of Dynamic Marketing Capability. Moreover, although our results contradict previous researches related to Dynamic Marketing Capability and Network Capability, we give a new perspective to the body literature of both or in short the dark side, of these 2 new theories. Lastly, we support previous research about the dark side of strategic orientation, specifically market and entrepreneurial orientations, to have no influence on NPD performance.

This research has several theoretical implications. First, New perspective on the body literature of Dynamic Marketing Capability and Network Capability which are not related to NPD Performance. Second, there is a relationship between strategic orientation with Dynamic Marketing Capability, which has not been explored before. Third, this research also supported a few researches which emphasize dark side of Market and Entrepreneurial Orientations. This research also contributes to managerial implication, first to implement and develop the network externalities as it positively influences NPD Performance. Managers also need to balance between Market Orientation and Entrepreneurial Orientation so that there will be no information overload or creating inertia.

Furthermore, our research has several limitations. First, small number of samples. Suggestion for future research is to conduct research with large number of samples which might lead to different perspectives. We also didn't specify the industry, hence this research can only conclude based on general view. Future research could specify more on 1 industry which might also lead to different perspectives. There also appears a shifting theory from Network Capability to Dynamic Network Capability which would be interesting to find the relationship between the Dynamic Network Capability and NPD Performance.

\section{References}

Adis, A.-A. A. (2009). Factors Affecting New Product Development in Malaysian Manufacturing Industry. International Bulletin of Business Administration.

Am et al., J. B. (2020, June 17). Innovation in a crisis: Why it is more critical than ever. Retrieved from McKinsey \& Company: https://www.mckinsey.com/business-functions/strategy-and-corporatefinance/our-insights/innovation-in-a-crisis-why-it-is-more-critical-than-ever

bisnis.com. (2021, March 26). 6 Tantangan yang Dihadapi CFO di Era Pandemi Covid-19. Retrieved from Ekonomi: https://ekonomi.bisnis.com/read/20210326/9/1372777/6-tantangan-yang-dihadapi-cfodi-era-pandemi-covid-19

Cassia, L., \& Massis, A. D. (2012). Strategic innovation and new product development in family firms. International Journal of Entrepreneurial Behaviour \& Research, 198-232.

Cubic. (n.d.). Ansoff Matrix Sebagai Tools Business Development. Retrieved from Cubic: https://cubic.id/journals/ansoff-matrix-sebagai-tools-business-development

Eisenhardt, K. M., \& Martin, J. A. (2000). Dynamic Capabilities: What Are They? Strategic Management Journal, 105-1121.

Ende et al., S. (2020). The Mediating Dynamic Capabilities In The Relationship Between Knowledge Management, Strategic Orientation In Improving Business Performance In Interior Design 131 
Companies In Province West Java And Banten, Indonesia. INTERNATIONAL JOURNAL OF SCIENTIFIC \& TECHNOLOGY RESEARCH, 4703-4707.

Feng et al., T. (2012). Customer orientation for decreasing time-to-market of new products: IT implementation as a complementary asset. Industrial Marketing Management, 929-939.

Fraenkel et al., S. (2016). Salesforce management factors for successful new product launch. Journal of Business Research, 5053-5058.

Gabbay, S. M., \& Leenders, R. T. (1999). Corporate Social Capital and Liability. Massachusetts: Kluwer Academic Publishers.

Gu et al., D. (2019). Social Media-Based Health Management Systems and Sustained Health Engagement: TPB Perspective. International Journal of Environmental Research and Public Health.

GURCAYLILAR-YENIDOGAN, T., \& AKSOY, S. (2018). APPLYING ANSOFF'S GROWTH STRATEGY MATRIX TO INNOVATION CLASSIFICATION. International Journal of Innovation Management.

Hair et al. (2014). Partial least squares structural equation modeling (PLS-SEM).European Business Review, 106-121.

Iamratanakul, S. (2014). Strategic Management of New Product Development Projects. 2118-2125.

Jeong et al., I. (2006). Antecedents and consequences of the strategic orientations in new product development: The case of Chinese manufacturers. Industrial Marketing Management, 348-358.

Junfeng, Z., \& Wei-ping, W. (2017). Leveraging internal resources and external business networks for new product success: A dynamic capabilities perspective. Industrial Marketing Management, 170-181.

Mitręga, M. (2020). Dynamic marketing capability-refining the concept and applying it to company innovations. Journal of Business \& Industrial Marketing, 193-203.

Molina-Castillo et al., F.-J. (2011). Product Quality and New Product Performance: The Role of Network Externalities and Switching Costs. Product Development \& Management Association, 915-929.

Montani, F., \& Staglianò, R. (2021). Innovation in times of pandemic: The moderating effect of knowledge sharing on the relationship between COVID-19-induced job stress and employee innovation. $R \& D$ Management.

Morgan et al, T. (2014). The dark side of the entrepreneurial orientation and market orientation interplay: A new product development perspective. International Small Business Journal, 1-21.

Mu et al., J. (2017). Strategic orientation and new product development performance: The role of networking capability and networking ability. Industrial Marketing Management, 187-201.

Najafi-Tavani et al., S. (2016). Market orientation, marketing capability, and new product performance: The moderating role of absorptive capacity. Journal of Business Research, 5059-5064.

Sajid et al., M. (2015). Role of Innovation in the Development of New Products for Improving Organizational Performance. Journal of Advanced Management Science, 261-264.

Schiller, D. T. (2020, July 31). Opportunity and innovation in a time of pandemic. Retrieved from Deloitte Insights: https://www2.deloitte.com/us/en/insights/deloitte-review/issue-27/opportunity-andinnovation-in-a-time-of-pandemic.html

Schilling, M. A., \& Hill, C. W. (1998). Managing the New Product Development Process: Strategic Imperatives. The Academy of Management Executive, 67-81.

Srinivasan et al., R. (2004). First in, First out? The Effects of Network Externalities on Pioneer Survival. Journal of Marketing, 41-58.

Stopher, P. R. (2016). "Survey and Sampling Strategies" In Handbook of Transport Modelling.

Teece et al., D. J. (1997). Dynamic Capabilities and Strategic Management. Strategic Management Journal, 509-533.

Teece, D. (2007). Explicating Dynamic Capabilities: the nature and microfoundations of (sustainable) enterprise performance. Strategic Management Journal, 1319-1350.

Tolonen et al., A. (2017). Supply chain capability creation - The creation of the supply chain readiness for a new product during product development process. International Journal of Production Economics, 237-245.

Wang, F., \& Dang, X. (2013). The relationship among high-tech enterprises' Strategic orientation, Network capability and Innovation Performance. International Conference on Information Management, Innovation Management and Industrial Engineering, 484-487'.

Xu et al., H. (2018). Facilitating dynamic marketing capabilities development for domestic and foreign firms in an emerging economy. Journal of Business Research, 141-152.

Zhou, K. Z., \& Li, C. B. (2010). How strategic orientations influence the building of dynamic capability in emerging economies. Journal of Business Research. 
Zirger, B. J., \& Maidique, M. A. (1990). A Model of New Product Development: An Empirical Test. Management Science, 867-883.

Appendix

New product development performance (adopted from Song \& Parry, 1997 and Kleinschmidt \& Cooper,1991 in Mu et al., 2017)

1. Relative sales, relative market share, relative return on investment (please focus on a most recent new product project in past three years)

a. Relative to your firm's other new products, this product is very successful in terms of sales

b. Relative to your firm's other new products, this product is very successful in terms of market share

c. Relative to your firm's other new products, this product is very successful in terms of return on investment

d. Relative to competing products in the market, this product is very successful in terms of sales

e. Relative to competing products in the market, this product is very successful in terms of market share

f. Relative to competing products in the market, this product is very successful in terms of return on investment

g. Relative to your firm's original objectives for this product, this product is very successful in terms of sales

h. Relative to your firm's original objectives for this product, this product is very successful in terms of market share

i. Relative to your firm's original objectives for this product, this product is very successful in terms of return on investment

2. Meeting objectives (please focus on a most recent new product project in past three years)

a. Relative to your firm's original objectives for this product, this product is very successful in terms of customer satisfaction

b. Relative to your firm's original objectives for this product, this product is very successful in terms of technological advancement

c. Relative to your firm's original objectives for this product, this product is very successful in terms of overall performance

\section{Strategic Orientation (adopted from Mu et al., 2017)}

Market orientation (adopted from Jaworski \& Kohli, 1993 in Mu et al., 2017)

A. Market intelligence collection

1. In this business unit we meet with customers at least once a year to find out what generation products/services they will need in the future

2. In this business unit, we poll end-users at least once a year to assess the quality of our products/services

3. We often talk with or survey those who can influence our end users' purchases (e.g., retailers or distributors)

4. In this business unit, intelligence on our competitors is generated independently by several departments

5. We periodically review the likely effect of changes in our business environment (e.g., regulations) on customers

B. Market intelligence dissemination

1. We have interdepartmental meetings at least once a quarter to discuss market trends dissemination and developments

2. Marketing personnel in our business unit spend time discussing customers' future needs with other functional departments

3. Our business unit periodically circulates documents (e.g., reports, newsletters) that provide information on our customers

4. When something important happens to a major customer or market, the whole business unit knows about it in a short time

5. Data on customer satisfaction are disseminated at all levels in this business unit on a regular basis

C. Responsiveness to market intelligence

1. It takes us forever to decide how to respond to competitor price changes (R)

2. For various reasons, we tend to ignore changes in our customers' product/service needs (R)

3. We periodically review our product/service development efforts to ensure that they are in line with what 
customers want

4. If a major competitor were to launch an intensive campaign targeted at our customers, we would implement an immediate response

5. Customer complaints fall on deaf ears in this business unit(R)

6. Even if we came up with a great marketing plan, we probably would not be able to implement it in a timely fashion (R)

Entrepreneurial Orientation (adopted from Covin \& Slevin, 1989 in Mu et al., 2017)

Innovativeness

1. In general, the top managers of my firm favor:

a. A strong emphasis on the marketing of tried-and-true products or services

b. A strong emphasis on R\&D, technological leadership, and innovations

2. How many new lines of products or services has your firm marketed in the past five years (or since its establishment)?

a. No new lines of products or services

b. Very many new lines of products or services

c. Changes in product or service lines have been mostly of a minor nature

d. Changes in product or service lines have usually been quite dramatic

\section{Proactiveness}

In dealing with its competitors, my firm...

1a. Typically responds to actions which competitors initiate

1b. Typically initiates actions to which competitors then respond

2a. Is very seldom the first business to introduce new products/services, administrative techniques, operating technologies, etc.

2b. Is very often the first business to introduce new products/services, administrative techniques, operating technologies, etc.

3a. Typically seeks to avoid competitive clashes, preferring a "live-and-let-live" posture

3b. Typically adopts a very competitive, "undo-the-competitors" posture

\section{Risk-taking}

1. In general, the top managers of my firm have...

a. A strong proclivity for low-risk projects (with normal and certain rates of return)

b. A strong proclivity for high-risk projects (with chances of very high returns)

2. In general, the top managers of my firm believe that...

a. Owing to the nature of the environment, it is best to explore it gradually via cautious, incremental behavior

b. Owing to the nature of the environment, bold, wide-ranging acts are necessary to achieve the firm's objectives

3. When confronted with decision-making situations involving uncertainty, my firm....

a. Typically adopts a cautious, "wait-and-see" posture in order to minimize the probability of making costly decisions

b. Typically adopts a bold, aggressive posture in order to maximize the probability of exploiting potential opportunities

Dynamic Marketing Capability (adopted from Li, 2015 in Falasca et al., 2017)

1. Our company regularly conducts systematic assessments on the status of customers and competitors

2. Key market information can be effectively distributed and shared among different departments within our company

3. Important market information can be quickly shared with top executives within our company

4. Managers at different levels within our company have appropriate marketing decision making power

5. Important marketing decisions can be adapted to reflect environmental changes

6. The marketing department in our company can coordinate effectively with other functional areas

7. Our company has the ability to distribute marketing information (such as product information) accurately to target customers

8. Our company has the ability to use different communication methods in marketing activities

9. Lead times from R\&D to market at our company is shorter when compared to other companies in our 
industry

Networking capability (adapted from Mu \& Di Benedetto, 2012 in Mu et al., 2017)

1. Finding network partners

a. We have a system in place to help us search locally to find proper network partners

b. We have a system in place to help us search globally to identify appropriate network partners

c. We have a system in place to help us search widely to look for right partners

2. Managing network relationship

a. We can design appropriate mechanism to navigate the dynamics of partner network

b. We can fine-tune network partnership relationships

c. We constantly assess and analyze our relationships with partners so that we know what adjustments to make

d. We can dynamically integrate networking activities into our business operational process

3. Leveraging network relationship

a. We can find partners to count on in time when the need arises

b. We can be quite accessible to our partners in a timely fashion

c. We can get the needed assistance from our partners in an accurate and timely manner

d. Our partners can refer us to a third party who could help if the partners cannot provide direct help

Network Externalities (Molina-Castillo et al., 2011)

Indirect network externalities

1. The number of complementary products offered by other companies has increased as our product sales increase.

2. The services offered by other companies relating to our product (such as training and support) have increased with our installed base.

Direct network externalities

1. The increase in installed base of our product has led directly to more benefits for the user.

2. A higher installed base means that our users enjoy more benefits by virtue of the installed base.

3. The number of users using the product has increased the utility of the product. 